\title{
ICT training of university teachers in a Personal Learning Environment. Project DIPRO 2.0.
}

\author{
Julio Cabero Almenara ${ }^{1,}$, Verónica Marín Díaz ${ }^{2}$ \\ 'Departamento de Didáctica y Organización Escolar y Métodos y Diagnóstico en Investigación, Universidad \\ de Sevilla, Spain \{cabero@us.es\} \\ 2Departamento de Educación, Universidad de Córdoba, Spain \{ed1madiv@uco.es\} \\ Received on 9 January 2012; revised on 27 January 2012; accepted on 13 February 2012; published on 15 July 2012
}

DOI: $10.7821 /$ naer.1.1.2-6

\begin{abstract}
Developing an information and knowledge society involves the incorporation of technological tools into education. This can only happen if teachers are properly qualified to include such tools into the classroom dynamics. The present article brings to the forefront a training proposal framed within an R\&D project funded by the Spanish Ministry of Science and Innovation under the title of "Design, production and evaluation in a 2.0 learning environment for the training of university teachers in the educational use of Information and Communication Technologies (ICTs) (EDU2009-08 893)," which has as its aim to incorporate technology tools both into classroom dynamics and into teachers' professional development.
\end{abstract}

KEYWORDS: LEARNING ENVIRONMENT; TEACHER TRAINING; UNIVERSITY; INFORMATION TECHNOLOGY

\section{INTRODUCTION}

It is only logical to accept that the university should not be relegated to the margins of the society in which it operates, a view which is currently gaining importance with the institution's orientation towards the European Higher Education Area (EHEA). Among the transformations it is going through, there is a strong presence of the Information and Communication Technologies (ICT) at the university stage of education. This trend implies new challenging situations such as the technological and educational training of both teachers and students in these technologies.

The implementation of the EHEA has involved going from a university model in which the only source of knowledge was the teacher, to one in which the teacher figure becomes a counsellor and/or guide of the students learning process. The students' role has also changed, and now they set the pace of their formation and have become active learners. The evolution of traditional learning models also involves a modification of traditional teaching models, which are now trying to overcome the traditional unidirectional approach and embrace continuous teacher-student feedback.

Traditionally, scholars have been socialized into teaching models anchored in the transmission of knowledge, and consequently the new incorporation of ICT to the professional development of university teaching goes hand in hand with the development of three types of knowledge, which according to Uzunboylu, Bicen, and Cavus (2011) are related to: the growth of scientific knowledge, which requires the development of the necessary skills for the search, selection and analysis of information; the popularity rise of the digital culture, in which critical thinking processes are of greater importance as they result from an insatiable quest for information; and, finally, by the development of learning processes without time restrictions, i.e., learning that can be done anytime and anywhere. We can add to these the technological knowledge of the pedagogical content suggested by Chai, Koh, Tsai, and Tan (2011), which arises as a response to the problems caused by the integration of ICT into the classroom that comes with the development of the teaching-learning process. The dissemination of this knowledge will be a role of the university, and it will become a way to guarantee development and progress of the institution in particular and of our society in general (Báez, 2005).

In short, the technological training of university teachers will involve the development of an experience in itself (Postareff, Lindblom-Ylänne, \& Nevgi, 2007).

Against this background, the profile of university teachers will be characterized by these roles:

1. "Preparation to convey the relevance of the existing scientific and cultural knowledge.

2. Ability to organize the selection and presentation of knowledge to students.

3. Being a motivator and a facilitator of student learning.

4. Designing the necessary curriculum developments.

5. Collaborating with other professionals in the professional and academic guidance of students.

6. Facilitating the connection between the classroom and the social reality.

7. Enhancing a reflective and research-oriented observation of their actions." (Martínez, 2004, pp. 129-130)

Accordingly, and as Marrero (2003) recalls, present-day society and ICT oblige universities to be active elements in its development, in a way that the introduction of ICT becomes of great relevance in the future of higher education. One reflection of this is the report "Computer and informational skills in grade studies", written by the joint committee CRUE-TIC and REBIUN (2009), which reflects on the need to provide teacher training for the development of their computer and informational skills.

The reality of university classrooms, therefore, reflects a gradual incorporation of ICT in the daily lives of students. The study conducted by EDUCAUSE in 2007 showed that $29.4 \%$ of 
the students used wikis in their daily lives, $24.3 \%$ used instant messaging, $17.4 \%$ used electronic calendars, $11.6 \%$ of them used blogs, $4.3 \%$ used microblogs and $2.8 \%$ of them used social bookmarking. Given this situation, it is necessary for teachers to be provided with a technological background so that they can respond to the demands that students may present. Consequently, universities are now investing on virtual teaching, which according to Uceda and Barro (2010) can be appreciated in the $79 \%$ of the possible teaching initiatives that were already carried out through ICT in 2010.

The development of technological university teaching currently goes hand in hand with the so-called Web 2.0 tools, in a way that even curriculum materials are designed around these in order to integrate the institution in the different social realities (Conole \& Alevizou, 2010), hence strengthening the connection between the university and the reality of our society.

One way to cover these new training scenarios are called Personal Learning Environments (PLE), which help teachers to integrate ICT within and outside the classroom.

However, in order for the university teacher to have the necessary technology skills to contribute to the real development of University 2.0 and Teaching 2.0 (Cabero, 2009) we must never lose sight of the following objectives:

- Training should promote and expand the use of technological tools.

- The formative dimension of university communities, made up of various institutions, should be strengthened.

- ICT should be presented as a way to stimulate the improvement of the teaching quality (Mellado, Talavera, Romero, \& García, 2011).

The educational implications of incorporating ICT into university teaching will be related to aspects such as:

- Understanding and designing them as horizontal-oriented social spaces.

- Being information-rich environments.

- Being multifunctional, designed both for action and for reflection.

- Facilitating independent and collaborative learning.

- Allowing the development of mash-ups of several materials.

- Facilitating the creation of learning networks (Marín \& Cabero, 2010).

\section{PERSONAL LEARNING ENVIRONMENTS}

The studies which have previously focused on PLE are numerous and diverse and, in general terms, could be grouped in two major trends: the technological/instrumental approach and the pedagogical/educational approach.

From a technological/instrumental perspective, PLE are defined as a set of learning tools, services and artefacts collected from diverse backgrounds and environments to be used by people in their formative actions. From this perspective, Fiedler and Pata (2009) define them as a collection of tools, materials and human resources that a person knows and has access to in the context of an educational project at a given point in time. Lubensky (2006) defines PLE as the sum of virtual learning environments and electronic portfolios or e-portfolios. According to this author, some of the defining characteristics of
PLE are that: there is an unlimited variety, they are affordable for everyone, not restricted to time limitations, open to continuous interaction, sharing and connecting, student-focused, and with content which can be managed through simple tools. In a similar way, Amine (2009) and Reig (2009) understand them as a self-defined collection of services, tools and devices which help students and teachers to build Personal Knowledge Networks (PKN), which connect tacit knowledge nodes (persons) to explicit knowledge nodes (information).

We can therefore say that these authors come to emphasize the importance of the relationship between an environment and an educational project, although they do focus mainly in their purely technological aspect.

The second approach noted above emphasizes the educational applications of PLE. From this perspective, PLE could be considered to be systems that help students and teachers to take control and manage their own learning. This includes providing support to set their own learning goals, manage their learning content, formalize the learning process, communicate with others throughout it, and achieve their learning objectives. As noted by Casquero, Portillo, Ovelar, Romo, and Benito (2010, p. 293), "a personal learning environment is an attempt to create an appropriate student-centred environment that incorporates all the tools, services, content, data and people involved in the digital learning process."

If we take into account this second perspective, we are not mistaken stating that PLE are gaining relevance in the universe of 2.0 tools, and can be understood as a strategy (or as tools, for some) that can compete with the rigidities of the traditional elearning platforms (i.e. the Virtual Learning Environments (VLE)), as the PLE try to overcome the current e-learning platforms (the Learning Management Systems (LMS)). Even though these helped teachers and the university in the development of education, spontaneous participation of the students was very limited (Dabbagh \& Kitsantas, 2012), and lead us to make in virtual environments the same "banking education" mistakes (using Paulo Freire's terminology) we were already making in traditional analogue formation.

There is a large divergence of views on the purpose of PLE. On the one hand, authors such as Martindale and Dowdy (2010) and Mödritscher (2010) suggest that PLE promote the possibility of working in a collaborative and cooperative way among teachers, students and among both collectives. Other scholars refer to them merely as a strategy that develops within informal and non-formal learning (Adell, 2011). We share the philosophy of Casquero, Portillo, Olvear, Romo, and Benito (2008) as well as that of Downes (2010), who understand PLE as a technologically mediated communication environment in which the learners develop their learning process through various tools, all placed within that platform. For us PLE are teaching strategies and technologies that help students take control of their own learning process. This process involves a number of aspects, such as:

- Identifying their own learning objectives.

- Controlling the learning process, both regarding the designation of contents and the learning objects to work with. (Cabero, Marín, \& Infante, 2011) 
The debate about the problems that PLE imply goes beyond these considerations, and there are several lines of discussion on various issues ranging from whether PLE can be generated only in informal and non-formal training or if they can also work in formal environments; or whether PLE could be connected to highly institutionalized training activities, not to mention the role that teachers and students play in this new approach in which they organize and structure their own formation.

In short, the main objective of a PLE will be to create an environment that encourages teaching innovation, in which information, research, connections and collaboration will be at the core of their development.

\section{PROJECT DIPRO 2.0}

Project DIPRO 2.0 ("Diseño, producción y evaluación en un entorno de aprendizaje 2.0 para la capacitación del profesorado universitario en la utilización educativa de las Tecnologías de la Información y Comunicación (TIC)"), is a R\&D project (EDU2009-08 893) funded by Ministry of Science and Innovation of the Spanish Government, which pursues a set of objectives:

(1) To develop basic topics by consensus between different professionals in the field of Educational Technology (ET) on the most significant areas in which faculty should be trained for the educational use of ICT.

(2) To create a telematic learning environment under the Web 2.0 umbrella, aimed at university teacher training in the acquisition of the different skills and competences needed for the use and integration of ICT into their work.

(3) To validate the telematic learning environment, both regarding the suggested content structure, as well as the different communication tools created (blogs, wikis, etc.).

(4) To create a virtual community of faculty concerned about the educational use of ICT and teacher training for the use of ICT.

These objectives are structured around five key areas: the possibilities of learning through networking; educational characteristics and structure of the materials used for training in virtual environments, designed from the perspective of PLE; the training opportunities provided by learning environments designed from a 2.0 perspective; the training of university teachers in the field of ICT; and the level of training and satisfaction that students reach with these training actions. All these are developed through a specific learning environment designed for the project, which we have called DIPRO 2.0 (Fig. $1)$.
Figure 1. DIPRO 2.0 portal.

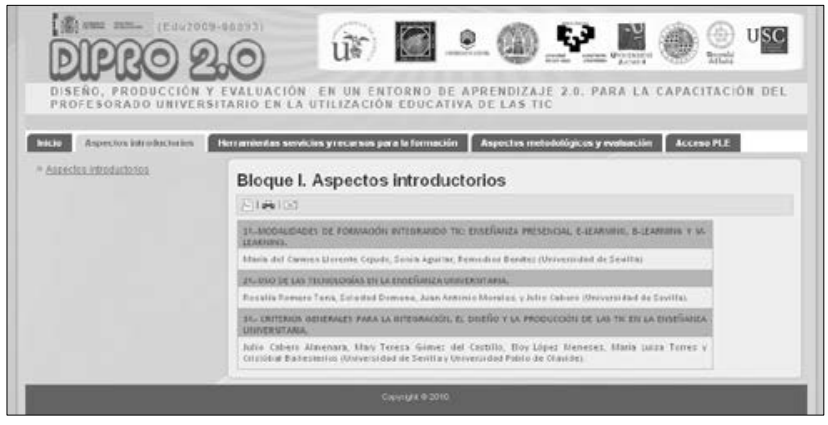

The DIPRO 2.0 learning environment has three main features:

a) From a technical point of view, it was designed with an open structure to avoid the need for any other specific software, i.e., the environment has been developed using preferably open software. It has been created with platforms such as Joomla, OKI-Bus or Moodle as LMS.

b) It has specific areas to enable the acquisition and localization of information and content related to the didactic use of ICT in university learning contexts, in which the users rather than finding formalized content can find different Learning Objects (LO) in different formats (PDF, video, podcast, audio, etc.) and suggested guidelines to undertake a series of activities (Fig. 2).

c) There is an area for the students to build their own PLE, where the different learning objects considered to be useful for the acquisition of different skills and capabilities can be stored.

Figure 2. DIPRO 2.0 section, conceived as a repository for LO.

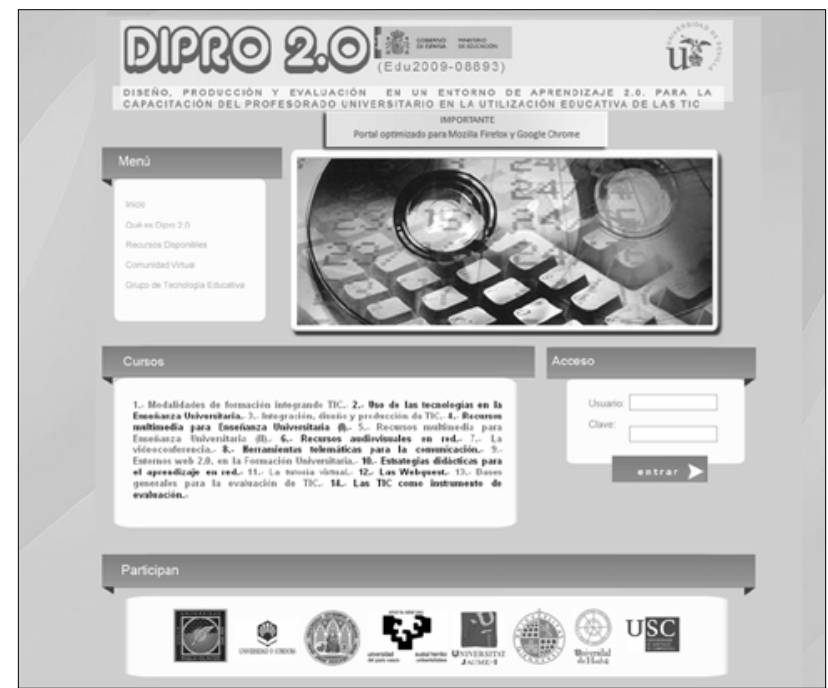

After carrying out of a Delphi study among a group of experts on ICT applied to education, the blocks of contents developed in the learning environment were grouped in three different areas. The three main sections were: "Introductory Aspects", "Tools, Services and Training Resources" and "Methodological Aspects and Assessment." The content was divided into 14 teaching units: 1. Training methods and the integration of ICT; 2. Use of technology in university education; 3 . Integration, design and production of ICT; 4. Multimedia resources in higher education (I); 5. Multimedia resources in higher education (II); 6 . Networked audiovisual resources; 7. Videoconferences; 8. 
Telematic tools for communication; 9. Web 2.0 environments in higher education; 10 . Teaching strategies in networked learning; 11. Virtual mentoring; 12. Webquests; 13. Bases for ICT evaluation; and 14. ICT as an assessment tool. The aim behind these units and their activities is to offer the teachers sufficient knowledge about the most significant aspects of the university use of ICT.

As for the PLE environment, once logged in, the user will find an empty platform (Fig. 3) that the teachers must design and fill to match their needs, both regarding the training activities they want to carry out with their students, or themselves, and the different web 2.0 tools they might want to use in their PLE.

Figure 3. PLE of project DIPRO 2.0.

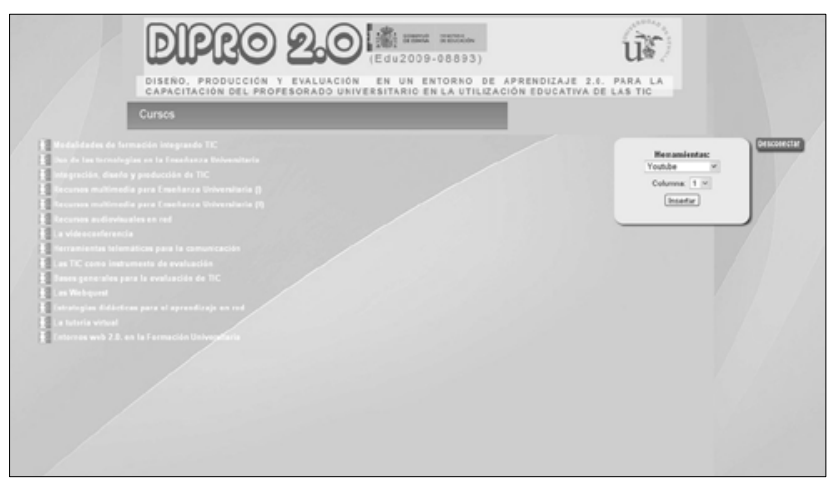

Our intention is to use all the potential that the available tools have to offer for teachers to develop several basic metacognitive processes such as reading, reflecting and sharing, which according to Adell and Castañeda (2010) are essential and enhanced through the use of this 2.0 platform.

The web 2.0 tools suggested for the creation of the PLE can be divided in three different types depending on their purpose: information access, creation and editing, and social interaction. In the first group we can find tools such as Google Calendar, Google Maps, YouTube, Flickr, Dropbox, Delicious or Wikipedia; in the second type we can find Dropbox; in the third one, resources such as Facebook, Twitter or Hi5. These tools are integrated into the environment as widgets (Fig. 4), and some of their elements can be customized (tool selection, situation, and frame colour).

Figure 4. Web 2.0 tools of the DIPRO 2.0 PLE.

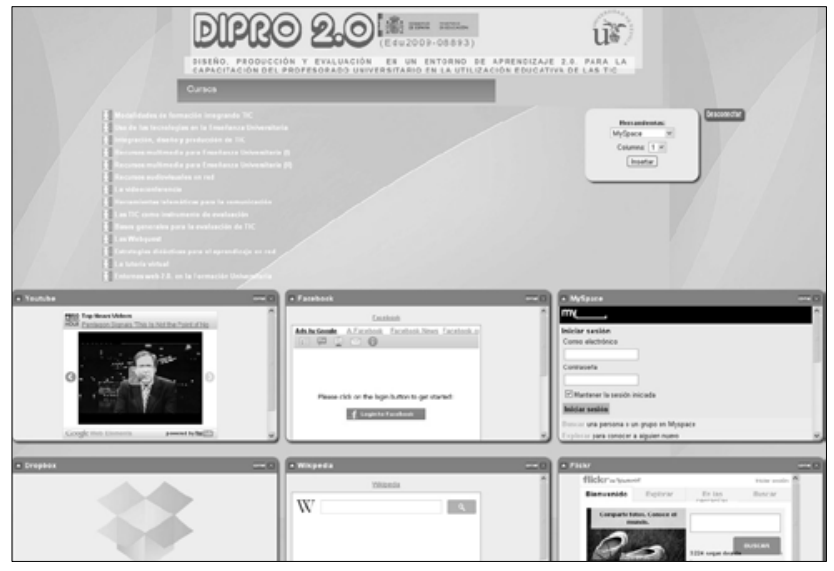

This learning environment also includes the possibility of incorporating an LMS through the Moodle platform (Fig. 5), in which the teacher can develop specific training activities.

Figure 5. PLE within DIPRO 2.0

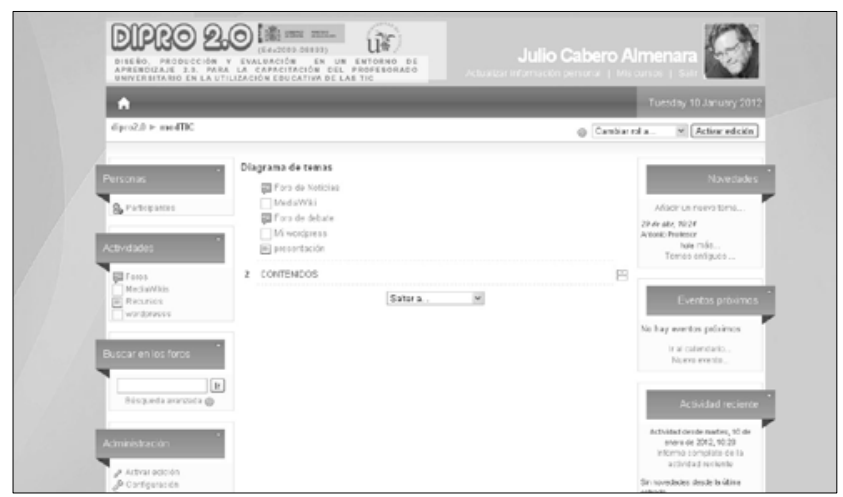

\section{SOME FINAL THOUGHTS}

Working in the University 2.0, as has already been pointed out (Pedreño, 2009), implies the continued development of learning processes by teachers in order to respond to the needs that the technological society of the 21 st century is demanding.

This University 2.0 must try to overcome these barriers that Renzel et al. (2010) note in their research, related to the difficulties, both technical as well as of lack of knowledge, of what it means to work in a collaborative and/or cooperative way.

The incorporation of Web 2.0 and its tools into university education will involve more personal, social and dynamic learning processes and will give the institution the role of developer of 2.0 learning (Shang, Li, Wu, \& Hou, 2011; Danciu \& Grosseck, 2011), hence giving educators an opportunity, as stated in the Bricall report (2000), to develop their careers with these tools. The development of PLE will imply the growth of a new working philosophy, a collaborative-cooperative approach, often asked of university students. They are a different way of understanding university education in these times of turbulent change, and are understood as an innovation tool to serve the teaching community. We must be aware that PLE can be of many different natures, born from different philosophies and ways of seeing, feeling and understanding the various Web 2.0 tools available for teachers. Personal teaching and learning environments will give teachers more control over their learning experiences, and allow them to manage their resources, the work produced with them and the activities in which they participate.

We would like to conclude noting that our research project is currently under development, and four different actions are being undertaken: selection of the content blocks, selection of LOs, design and construction of the training activities, and technological development of the learning environment. The next step to be carried out will be its validation taking into account expert and user feedback.

\section{REFERENCES}

Adell, J. (2011, February 13). Entrevista con Jordi Adell para la gestión y transferencia del conocimiento. ¿Qué es un PLE? [Video file]. Retrieved from http://www.youtube.com/watch?v=PblWWlQbkUQ

Adell, J., \& Castañeda, L. (2010). Los Entornos Personales de Aprendizaje (PLEs): una nueva manera de entender el aprendizaje. In R. Roig Vila \& M. Fiorucci (Eds.), Claves para la investigación en innovación y calidad educativas. La integración de las Tecnologías de la Información y la Comunicación y la Interculturalidad en las 
aulas. Strumenti di ricerca per l'innovazione e la qualità in ambito educativo. La Tecnologie dell'Informazione e della Comunicazione e l'Interculturalità nella scuola (pp. 19-30). Alcoy-Roma: MarfilUniversità degli Studi Roma Tre.

Amine, M. (2009, April 22). PLE - PKN [Web log post]. Retrieved from http://mohamedaminechatti.blogspot.com/2009/04/ple-pkn.html

Báez, R. (2005). Uso y aplicación de la web en la práctica docente universitaria: reflexión y experiencia. Cuadernos de Pedagogía Universitaria, 2(3), 21-24.

Bricall, J. M. (2000). Informe Universidad 2000. Retrieved from http://www.oei.es/oeivirt/bricall.htm

Cabero, J. (2009). Educación 2.0 ¿Marca, moda o nueva visión de la educación? In C. Castaño (Ed.), Web 2.0. El uso de la web en la sociedad del conocimiento. Investigaciones e implicaciones educativas (pp. 9-30). Venezuela: Universidad Metropolitana.

Cabero, J., Marín V., \& Infante A. (2011). Creación de un entorno personal para el aprendizaje: Desarrollo de una experiencia. Edutece. Revista Electrónica de Tecnología Educativa, 38. Retrieved from http://edutec.rediris.es/Revelec2/Revelec38/pdf/Edutece_38_Cabero_Marin_Infante.pdf

Casquero, O., Portillo, J., Ovelar, R., Romo, J., \& Benito, M. (2008). $i$ Google and gadgets as a platform for integrating institutional and external services. Retrieved from http://ftp.informatik.rwthaachen.de/Publications/CEUR-WS/Vol-388/casquero.pdf

Casquero, O., Portillo, J., Ovelar, R., Romo, J., \& Benito, M. (2010). iPLE Network: an integrated eLearning 2.0 architecture from a university's perspective. Interactive Learning Environments, 18(3), 293-308. doi: 10.1080/10494820.2010.500553

Chai, C. S., Koh, J. H. L., Tsai, C. C., \& Tan, L. L. W. (2011). Modeling primary school pre-service teachers' Technological Pedagogical Content Knowledge (TPACK) for meaningful learning with information and communication technology (ICT). Computers \& Education, 57(1), 1184-1193. doi:10.1016/j.compedu.2011.01.007

Comisión Mixta CRUE- TIC y REBIUN (2009). Competencias informáticas e informacionales en los estudios de grado. Retrieved from http://cruetic.uii.es/index.php?option $=$ com remository $\&$ Itemid $=28 \&$ func $=$ start down\&id $=226$

Conole, G., \& Alevizou, P. (2010). A literature review of the use of web 2.0 tools in Higher Education. A report commissioned by the Higher Education Academy. Retrieved from http://www.heacademy.ac.uk/assets/EvidenceNEt/Conole_Alevizou 2010.pdf

Dabbagh, N., \& Kitsantas, A. (2012). Personal Learning Environments, social media, and self-regulated learning: A natural formula for connecting formal and informal learning. The Internet and Higher Education, 15(1), 3-8. doi: 10.1016/j.iheduc.2011.06.002

Danciu, E., \& Grosseck, G. (2011). Social aspects of web 2.0 technologies: teaching or teachers' challenges? Procedia Social and Behavioral Sciencies. 15. 3768-3773. doi: 10.1016/j.sbspro.2011.04.371

Downes, S. (2010). New Technology Supporting Informal Learning. Journal of Emerging Technologies in Web Intelligence, 2(1). 27-33. doi:10.4304/jetwi.2.1.27-33

EDUCAUSE Learning Initiative (ELI) (2007). The seven things you should know about Retrieved from http://www.educause.edu/7Things

Fiedler, S., \& Pata, K. (2009). Distributed learning environments and social software: In search for a framework of design. In S. Hatzipanagos \& S. Warburton (Eds.), Handbook of Research on Social Software and Developing Community Ontologies (pp. 145158). doi: 10.4018/978-1-60566-984-7.ch028

Lubensky, R. (2006). The present and future of Personal learning Environments. [Web log post]. Retrieved from http://www.deliberations.com.au/2006/12/present-and-future-ofpersonal-learning.html

Marín, V., \& Cabero, J. (2010). Del conocimiento del estudiante universitario sobre las herramientas 2.0. Revista Anales de la Universidad Metropolitana, 10 (2), 51-74. Retrieved from http://ares.unimet.edu.ve/academic/revista/anales10.2/documentos/pa g-51-74.pdf

Marrero, J. (2003). El entorno universitario y las nuevas tecnologías de la información y la comunicación. ¿Hacia dónde vamos? Docencia Universitaria, 4(2). 9-30. Retrieved from http://190.39.165.96/gsdl/collect/artculos/index/assoc/HASH0160.dir doc.pdf
Martindale, T., \& Dowdy, M. (2010). Personal learning environments. In G. Veletsianos (Ed.), Emerging technologies in distance education (pp. 177-193). Edmonton: AU Press, Athabasca University.

Martínez, J. (2004). La formación del profesorado y el discurso de las competencias. Revista Interuniversitaria de Formación del Profesorado, 18(3), 127-143. Retrieved from http://www.aufop.com/aufop/uploaded files/articulos/1212406727.p df

Mellado, E., Talavera, M. C., Romero, F., \& García, M. T. (2011). Las TIC como herramienta fundamental de la formación permanente en la Universidad de Sevilla. Pixel Bit, Revista de Medios y Educación, 39. 155-166. Retrieved from http://intra.sav.us.es:8080/pixelbit/images/stories/p39/12.pdf

Mödritscher, F. (2010). Towards a Recommender Strategy for Personal Learning Environments. Procedia Computer Science, 1(2), 27752782. doi:10.1016/j.procs.2010.08.002

Pedreño, A. (2009). ¿Qué puede ser la Universidad 2.0? Visión y Estrategias de actuación. [Web log post]. Retrieved from http://utopias-realidades.blogspot.com/2009/08/universidad-20.html

Postareff, L., Lindblom-Ylänne, S., \& Nevgi, A. (2007). The effect of pedagogical training on teaching in higher education. Teaching and Teacher Education, 23(5), 557-571. doi:10.1016/j.tate.2006.11.013

Reig, D. (2009, April 25) Entornos personales de aprendizaje. [Slide show] Retrieved from http://www.slideshare.net/dreig/ple-1340811

Renzel, D., Höbelt, C., Dahrendorf, D., Friedrich, M., Mödritscher, F., Verbert, K., Govaerts, S., Palmer, M., \& Bogdanov, E. (2010). Collaborative development of a PLE for language learning. International Journal of Emerging Technologies in Learning, 5(1) 31-40. doi:10.3991/ijet.v5s1.1196

Shang, S. S. C., Li, E. Y., Wu, Y., \& Hou, O. C. L. (2011). Understanding web 2.0 service models: A knowledge-creating perspective. Information \& Management, 48(4-5), 178-184. doi:10.1016/j.im.2011.01.005

Uceda, J., \& Barro, S. (2010). UNIVERSITIC 2010: Evolución de las TIC en el sistema Universitario Español 2006-2010. Retrieved from http://www.crue.org/export/sites/Crue/Publicaciones/Documentos/Un iversitic/UNIVERSITIC2010b.pdf

Uzunboylu, H., Bicen, H., \& Cavus, N. (2011). The efficient virtual learning environment: A case study of web 2.0 tools and windows live spaces. Computers \& Education, 56(3), 720-726. doi:10.1016/j.compedu.2010.10.014 